\title{
TINGKAT KENYAMANAN DI BERBAGAI TAMAN KOTA DI BANDAR LAMPUNG
}

\section{(COMFORT LEVEL AT VARIOUS CITY PARK IN BANDAR LAMPUNG)}

\author{
Oleh/By:
}

\author{
Bunga Choirunnisa, Agus Setiawan dan Niskan Walid Masruri \\ Jurusan Kehutanan Fakultas Pertanian Universitas Lampung \\ Jl. Soemantri Brojonegoro No. 1 Bandar Lampung \\ Email: bunga.choirunnisa@gmail.com \\ HP: +6281273323403
}

\begin{abstract}
ABSTRAK
Bandar Lampung merupakan kota yang cepat perkembangannya, akan berdampak pada meningkatnya kebutuhan hidup sehingga mendorong pembangunan untuk peningkatan kualitas dan kuantitas sarana prasarana penunjang. Diperlukan area Ruang Terbuka Hijau (RTH) sebagai penyeimbang lanskap perkotaan. Taman kota merupakan bagian dari RTH yang membantu meningkatkan kualitas ekologis dan lingkungan di sekitar taman itu berada. Penelitian ini bertujuan untuk mengetahui peranan dari taman kota dengan melihat tingkat kenyamanan yang diciptakan dengan metode Temperature Humidity Index, mengidentifikasi karakteristik pohon, dan mengetahui penilaian pengunjung di Taman Dipangga, Taman Kalpataru, dan Embung Taman Kota Way Halim. Hasil penelitian menunjukkan bahwa ketiga taman tersebut memiliki karakteristik pohon yang jenis dan kerapatannya tidak memenuhi standar yang dibutuhkan taman-taman tersebut. Berdasarkan nilai THI ketiga taman tersebut berada pada karakteristik tidak nyaman yaitu $>26$. Pengunjung memberikan penilaian baik pada ketiga taman tersebut hanya pada kemudahan akses dari tempat tinggal. Sedangkan penilaian pada kebersihan, kerapihan, fasilitas toilet, tempat duduk, tempat beribadah, dan fasilitas bermain anak memiliki penilaian sangat buruk.
\end{abstract}

Kata Kunci : Taman Kota Bandar Lampung, Tingkat Kenyamanan, THI

\begin{abstract}
Bandar Lampung is a city that is fast on the development, these would have an impact on the incresing life necessities thus prompt the development to increase the quality and quantity of supporting infrastructure. Green open space is required as a urban landscape stabilizer. City park is part of the green open space that helps to improve the ecological and environmental quality around the park is located. The purposes of the study were to determine the role of city park create the comfort level used Temperature Humidity Index method, to recognize the tree characteristics and to figure out the visitor assessment of facilities in Dipangga Park, Kalpataru Park and Retention Basin Way Halim City Park. The results showed that the tree characteristics on the all of the park had low density and do not meet standarts that should be required the parks. Based on the THI value all of the city parks were categorized as uncomfortable that is $>26$. All of parks reaped good visitors assessment only on the ease of access from their homes. While on the assessment of cleanliness, neatness, toilet, facilities seating, places of worship and a children's play facilities reaped the worst assessment.
\end{abstract}

Keywords : Bandar Lampung Urban Park, Comfort Level, THI 


\section{PENDAHULUAN}

Bandar Lampung merupakan kota yang pembangunan dan perkembangan terbilang cepat. Pembangunan kota dipicu oleh peningkatan jumlah penduduk dan peningkatan jumlah kendaraan yang akan berdampak pada meningkatnya kebutuhan hidup sehingga mendorong peningkatan kualitas dan kuantitas sarana prasarana penunjang.

Konversi lahan yang semula merupakan ruang tumbuh berbagai jenis vegetasi berubah menjadi lahan terbangun akan berpengaruh pada kualitas ekologis dan lingkungan perkotaan. Samadikun (2007) mengemukakan perkembangan kota yang tidak terkendali akan berimplikasi sangat serius pada lingkungan perkotaan tersebut. Implikasi peningkatan luasan perkerasan salah satunya adalah peningkatan temperatur udara yang mengakibatkan penurunan kenyamanan lingkungan (Saputro, Indung dan Sulistyantara, 2010).

Ruang terbuka hijau merupakan subsistem dalam sistem kota yang memiliki peranan penting bagi masyarakat kota. Taman kota merupakan bagian dari bentuk Ruang Terbuka Hijau (RTH) yang membantu meningkatkan kualitas ekologis dan lingkungan di sekitar taman itu berada. Sebagai bagian dari elemen pembentuk kota, taman kota memiliki banyak fungsi dalam kaitannya dengan fungsi sosial warga kota. Keberadaan Taman Kalpataru, Taman Dipangga dan Embung Taman Kota Way Halim yang merupakan bagian dari RTH Kota Bandar Lampung perlu dilakukan penelitian untuk mengetahui peranan dari taman kota tersebut dengan melihat tingkat kenyamanan yang diciptakan baik secara fisik maupun penilaian dari pengunjung. Hasil penelitian akan bermanfaat sebagai bahan dasar penggelolaan taman kota yang memberikan kenyamanan beraktivitas masyarakat urban.

\section{METODE PENELITIAN}

Penelitian ini dilaksanakan pada Bulan Maret - Mei 2016 di Taman Kalpataru, Taman Dipangga, dan Embung Taman Kota Way Halim di Kota Bandar Lampung. Data yang dihimpun yaitu berupa data primer meliputi temperatur udara, kelembaban udara relatif, karakteristik pohon (jenis dan kerapatan) dan penilaian pengunjung sedangkan data sekunder meliputi letak dan luas, topografi, kondisi iklim dan demografi lokasi penelitian.

Nilai temperatur udara dan nilai kelembaban udara relatif diukur menggunakan alat termohigrometer yang diletakkan 1,5 meter dari permukaan tanah pada waktu pagi hari (07.00-09.00) WIB, siang hari (12.00-14.00) WIB dan sore hari (16.00-18.00) WIB selama 10 hari cuaca cerah. Nilai temperatur udara dan nilai kelembaban udara relatif kemudian di analisis untuk mengetahui indeks tingkat kenyamanan (Temperature Humidity Index) menggunakan rumus : $\mathrm{THI}=0,8 \mathrm{~T}+(\mathrm{RH} \times \mathrm{T}) / 500$ (Nieuwolt dan Mc Gregor, 1998). Keterangan: $\mathrm{T}=$ Temperatur udara rata-rata $; \mathrm{RH}=$ Kelembaban udara rata-rata. Nieuwolt dan Mc Gregor (1998) menyatakan kriteria tingkat kenyamanan digolongkan menjadi tiga yaitu, nyaman dengan nilai THI 21-24, sedang dengan nilai THI 25-26, dan tidak nyaman dengan nilai $\mathrm{THI}>26$.

Data karakteristik pohon didapatkan dengan menggunakan metode sampling jenuh pada tiap lokasi penelitian. Data penilaian pengunjung terhadap fasilitas yang mendukung kenyamanan taman kota dilakukan dengan mewawancarai kepada 44 responden pada tiap lokasi yang di dapat dari formula slovin (Arikunto, 2011). Hasil wawancara kemudian dianalisis untuk mengetahui penilaian pengunjung terhadap ketiga taman kota tersebut. 


\section{HASIL DAN PEMBAHASAN}

\section{Temperatur Udara dan Kelembaban Udara}

Nilai temperatur udara ketiga lokasi taman kota dikelompokkan menjadi dua kategori yaitu kategori temperatur di dalam taman yang diperoleh dengan pengukuran rata-rata temperatur udara di titik tajuk rapat, tajuk sedang, dan tajuk jarang dan kategori di luar taman yang berlokasi 10 meter di luar taman. Nilai temperatur udara pada dua kategori di masingmasing taman tersebut ditunjukkan pada Tabel 1.

Tabel 1. Nilai rata-rata temperatur udara di dalam dan di luar lokasi.

\begin{tabular}{lcc}
\hline \multirow{2}{*}{\multicolumn{1}{c}{ Lokasi }} & \multicolumn{2}{c}{ Temperatur Udara Rata-rata $\left({ }^{\mathbf{0}} \mathbf{C}\right)$} \\
\cline { 2 - 3 } & di dalam & di luar \\
\hline Taman Dipangga & 30 & 30,5 \\
Taman Kalpataru & 30,1 & 30,9 \\
Embung Taman Kota Way Halim & 29,9 & 30,9 \\
\hline
\end{tabular}

Temperatur udara di dalam taman kota memiliki nilai yang lebih rendah dibandingkan dengan nilai temperatur udara di luar taman kota. Temperatur udara maksimun terjadi pada pengukuran saat siang hari dengan nilai temperatur udara mencapai $35,2^{\circ} \mathrm{C}$ dibandingkan dengan temperatur udara pagi dan sore hari yang memiliki nilai temperatur udara lebih rendah. (Mustika, 2001) menyatakan bahwa temperatur udara minimum bisa terjadi pada pukul 03.30-05.30 dan temperatur udara maksimum terjadi pada pukul 13.30-15.30 WIB.

Pengukuran dan pembagian kategori pada kelembaban udara harian pada dasarnya sama dengan pengukuran temperatur udara. Nilai kelembapan udara pada dua kategori di masingmasing taman ditunjukkan pada Tabel 2.

Tabel 2. Nilai rata-rata kelembaban udara di dalam dan di luar lokasi.

\begin{tabular}{lcc}
\hline \multirow{2}{*}{ Lokasi } & \multicolumn{2}{c}{ Kelembaban Udara Rata-rata (\%) } \\
\cline { 2 - 3 } & di dalam & di luar \\
\hline Taman Dipangga & 82,5 & 80,9 \\
Taman Kalpataru & 82,1 & 80,8 \\
Embung Taman Kota Way Halim & 85,6 & 83 \\
\hline
\end{tabular}

Kelembaban udara adalah banyaknya kadar air di udara. Air menguap ke udara lebih banyak pada siang hari dibandingkan dengan sore hari dan pagi hari. Angka kelembaban udara berkisar dari $0 \%$ - 100\%, nilai rata-rata kelembaban udara paling tinggi yang diukur pada saat penelitian dapat hingga mencapai nilai kelembaban udara relatif $99 \%$ yang terjadi pada pengukuran pagi hari di setiap taman kota.

Perbedaan komponen vegetasi dinilai memberikan pengaruh yang signifikan terhadap perbedaan nilai temperatur dan kelembaban udara di sekitar taman. Vegetasi berupa tegakan pohon merupakan komponen alam yang mampu mempengaruhi unsur-unsur iklim termasuk temperatur dan kelembaban udara. Pohon mampu mengurangi kecepatan angin dan mengarahkannya, dan tutupan tegakan pohon mampu menghalangi sinar matahari langsung ke permukaan tanah sehingga berpengaruh pada temperatur dan kelembaban udara. Sinar yang tegak lurus akan membuat temperatur lebih panas daripada sinar yang datangnya miring (Kastasapoetra, 2004).

Selain itu pohon juga merupakan struktur vegetasi yang paling efektif mereduksi temperatur dan meningkatkan kelembaban udara dibandingkan dengan semak dan rumput, karena pohon mampu berevapotranspirasi lebih baik dengan tajuknya yang rapat. Terlihat pada nilai temperatur lebih tinggi yang dihasilkan pada lokasi Taman Kalpataru yang terdapat lapangan bola yang lebih luas dengan ditumbuhi rumput daripada bervegetasi pohon. 
Penelitian yang dilakukan Sapariyanto, Yuwono dan Riniarti (2016) juga menunjukkan hal serupa bahwa temperatur udara yang dihasilkan di lapangan sepak bola pada pagi, siang, dan sore hari tertinggi dibandingkan dengan lokasi penelitian lainnya berupa pohon yang dapat menyerap sinar matahari.

Tingginya laju aktivitas kendaraan menjadikan faktor lain dalam perubahan temperatur yang signifikan. Dilihat dari taman-taman kota tersebut yang berada di tengah kota mengakibatkan taman langsung berbatasan dengan jalan raya, gedung dan pemukiman sehingga kondisi tersebut sangat jarang terdapat vegetesi. Menurut Dahlan (2011) menyatakan bahwa jalan aspal, paving block, tembok dan atap gedung merupakan sebagian contoh dari permukaan kota yang berpotensi menaikkan temperatur udara melalui refleksi, transmisi dan absorbsi radiasi matahari.

\section{Kerapatan Pohon}

Komponen penyusun vegetasi taman kota berpengaruh secara signifikan terhadap temperatur dan kelembaban udara bergantung salah satunya pada kerapatan dari pohon penyusun tersebut. Selain fungsi ekologis beberapa pohon ditanam karena memiliki fungsi estetika yang tepat untuk tumbuh pada taman-taman tersebut.

Hasil analisis vegetasi di Taman Dipangga, Taman Kalpataru, dan Embung Taman Kota Way Halim terdapat sebanyak 209 individu pohon dan 20 jenis pohon. Ketiga taman tersebut juga memiliki kategori kerapatan pohon yang berbeda dan disajian pada Tabel 3.

Tabel 3. Karakteristik komponen vegetasi di Taman Dipangga, Taman Kalpataru, dan Embung Taman Kota Way Halim.

\begin{tabular}{lccc}
\hline \multicolumn{1}{c}{ Lokasi } & Jumlah Individu & $\begin{array}{c}\text { Jumlah } \\
\text { Jenis }\end{array}$ & $\begin{array}{c}\text { Kerapatan } \\
\text { (ind/ha) }\end{array}$ \\
\hline Taman Dipangga & 43 & 10 & 63,24 \\
Taman Kalpataru & 97 & 8 & 36,88 \\
Embung Taman Kota Way Halim & 69 & 7 & 80,23 \\
\hline
\end{tabular}

Berdasarkan hasil penelitian Taman Kalpataru memiliki jumlah individu terbanyak namun memiliki nilai kerapatan pohon terendah. Nilai tersebut dikarenakan luas area Taman Kalpataru seluas 2,63 hektar tidak sesuai dengan jumlah pohon yang tumbuh pada area tersebut. Pohon yang tumbuh di Taman Kalpataru berada hanya pada pinggir taman saja. Pohon tumbuh mengelilingi lapangan sepak bola yang ada di tengah taman, sebagai fungsi utama yakni sarana olahraga tentu Taman kalpataru memiliki area terbuka tanpa pohon yang luas. Berikut karakteristik pohon yang tumbuh pada ketiga taman disajikan pada Tabel 4.

Tabel 4. Karakteristik pohon yang tumbuh pada ketiga taman.

\begin{tabular}{lllccc}
\hline & \multicolumn{2}{c}{ Spesies Pohon } & \multicolumn{3}{c}{ Jumlah Pohon di- } \\
\cline { 2 - 6 } No. & \multicolumn{1}{c}{ Nama Lokal } & \multicolumn{1}{c}{ Nama Ilmiah } & $\begin{array}{c}\text { Taman } \\
\text { Kalpataru }\end{array}$ & $\begin{array}{c}\text { Taman } \\
\text { Dipangga }\end{array}$ & $\begin{array}{c}\text { Embung } \\
\text { Taman Kota } \\
\text { Way Halim }\end{array}$ \\
\hline 1. & Mahoni & Swietenia mahagoni & 50 & 3 & 34 \\
\hline 2. & Cempaka & Magnolia champaca & 17 & - & - \\
\hline 3. & Flamboyan & Delonix regia & 23 & - & 6 \\
\hline 4. & Glodokan & Polyalthia longifolia & - & 1 & 11 \\
\hline 5. & Sonokeling & Dalbergia latifolia & 3 & - & - \\
6. & Ketapang & Terminalia catappa & 1 & - & - \\
\hline 7. & Jabon & Anthocephalus cadamba & 1 & - & - \\
\hline 8. & Akasia Daun Lebar & Acacia mangium & 1 & - & - \\
9. & Nangka & Artocarpus heterophyllus & 1 & - & - \\
\hline
\end{tabular}




\begin{tabular}{lllccc}
\hline & \multicolumn{2}{c}{ Spesies Pohon } & \multicolumn{3}{c}{ Jumlah Pohon di- } \\
\cline { 2 - 6 } No. & \multicolumn{1}{c}{ Nama Lokal } & \multicolumn{1}{c}{ Nama Ilmiah } & $\begin{array}{c}\text { Taman } \\
\text { Kalpataru }\end{array}$ & $\begin{array}{c}\text { Taman } \\
\text { Dipangga }\end{array}$ & $\begin{array}{c}\text { Embung } \\
\text { Taman Kota } \\
\text { Way Halim }\end{array}$ \\
\hline 10. & Akasia Daun Kecil & Acacia auriculiformis & - & - & 4 \\
11. & Kersen & Muntingia calabura & - & - & 6 \\
\hline 12. & Sukun & Artocarpus altilis & - & - & 1 \\
\hline 13. & Mangga & Mangifera indica & - & 2 & 7 \\
14. & Lamtoro & Leucaena leucocephala & - & 15 & - \\
\hline 15. & Palem Raja & Roystonea regia & - & 6 & - \\
16. & Johar & Cassia siamea & - & 8 & - \\
\hline 17. & Trembesi & Samanea Saman & - & 2 & - \\
18. & Cemara Laut & Casuarina equisetifolia & - & 1 & - \\
19. & Jambu Air & Syzygium aqueum & - & 1 & - \\
20. & Bungur & Lagerstroemia speciosa & - & 4 & - \\
\hline
\end{tabular}

Taman Kalpataru merupakan salah satu RTH di Kota Bandar Lampung yang masih baru. Taman ini didominasi oleh pohon mahoni pada area bermain anak dan juga tumbuh mengelilingi lapangan sepak bola berseling dengan pohon flamboyan. Waktu penanaman yang bersamaan saat pembuatan taman tersebut menjadikan pohon-pohon dengan jenis yang sama juga memiliki pengukuran diameter dan tinggi yang tidak jauh berbeda.

Pemilihan pohon mahoni untuk ditanam mengelilingi lapangan sepak bola pada Taman Kalpataru memang sangat cocok. Warna daun mahoni yang hijau cerah selain sebagai fungsi estetika taman juga sebagai pengarah dan pembatas jalan di malam hari, sehingga pengunjung yang berkendara di sisi lapangan sepak bola tidak berjalan melebihi batas, karena terdapat selokan-selokan besar yang berada tepat di sebelah pohon tersebut, hal ini sudah sesuai seperti yang diinstruksikan Departemen Pekerjaan Umum (1996).

Embung Taman Kota Way Halim menunjukkan hasil identifikasi yang serupa. Pohon mahoni tumbuh mendominasi di taman tersebut yang berada mengelilingi embung. Tujuannya yaitu sebagai pembatas untuk pengunjung yang berada di lokasi tersebut terhadap embung yang cukup dalam. Berdasarkan hasil penelitian Embung Taman Kota Way Halim memiliki nilai kerapatan pohon terbesar dibandingkan kedua taman lainnya. Taman ini ditumbuhi 69 pohon dengan luas 0,86 hektar. Pohon-Pohon yang ditanam dipilih dengan mempertimbangkan nilai estetika yang sangat baik. Terdapat pohon glodokan yang ditanam berjajar menyerupai pagar pada pintu masuk selain pohon mahoni yang mengelilingi Embung Taman Kota Way Halim.

Hasil analisis vegetasi pada Taman Dipangga dengan luas 0,68 hektar memiliki jenis pohon yang lebih variatif. Berbeda dengan dua taman lainnya yang tumbuh berkelompok dengan jenis yang sama pada satu areal. Suatu lanskap perkotaan dengan ditumbuhi pohon dengan keanekaragaman yang tinggi maka akan menambah fungsi estetika dari lanskap tersebut. Pohon-pohon yang tumbuh di Taman Dipangga memiliki diameter yang cukup besar-besar. Di tengah taman terdapat dua pohon trembesi yang sangat besar dengan lebar kanopi tajuk menutupi seluruh bagian tengah taman sehingga Taman Dipangga terlihat sangat rimbun dan teduh. Penutupan kanopi yang lebar akan membentuk daerah teduhan hijau yang memberikan kenyamanan di taman tersebut. Karena radiasi matahari memberikan pengaruh yang cukup besar pada kenyamanan, kanopi lebar mampu mengurangi radiasi matahari hingga $80 \%$ atau menjadi kurang dari $100 \mathrm{Watt} / \mathrm{m}^{2}$ (Irwan, 2007).

Kecenderungan kenyamanan tinggi pada area berstrata banyak dan juga jumlah vegetasi yang banyak diharapkan mampu memberikan penutupan kanopi yang semakin besar dan juga dapat mengahasilkan oksigen yang lebih banyak sehingga dapat membentuk efek kesejukan yang lebih besar (Irwan dan Kharuddin, 2010). Pohon trembesi yang tumbuh memang 
memiliki kaitan yang erat dengan kearifan lokal masyarakat yakni sebagai payung raksasa yang mampu menaungi/melindungi masyarakat dari bencana-bencana. Mulyana (2013) juga mengemukakan bahwa pemilihan jenis pohon pada taman kota sebaiknya mempertimbangkan kearifan lokal dengan memperhatikan jenis lokal (endemic) yang langka atau hampir punah untuk dipertahankan.

\section{Temperature Humidity Index}

Menurut Karyono (2005) salah satu jenis kenyamanan manusia berkaitan dengan keberadaan taman kota yakni kenyamanan termal. Tingkat kenyamanan termal pada manusia di berbagai wilayah telah dirumuskan melalui parameter iklim seperti temperatur udara, kelembaban relatif, radiasi matahari dan kecepatan angin.

Hasil pengamatan menunjukkan bahwa nilai THI ketiga lokasi penelitian termasuk dalam kategori tidak nyaman. Nilai THI yang melebihi dari 26 dijadikan parameter ketidaknyamanan manusia untuk beraktivitas di area tersebut. Nilai perhitungan THI dari Taman Dipangga, Taman Kalpataru dan Embung Taman Kota Way Halim disajikan pada Tabel 5.

Tabel 5. Nilai THI di berbagai Taman Kota Bandar Lampung.

\begin{tabular}{|c|c|c|c|c|c|}
\hline \multirow[b]{2}{*}{ Lokasi } & \multicolumn{3}{|c|}{ Faktor THI } & \multirow[b]{2}{*}{$\begin{array}{l}\text { Nilai } \\
\text { THI }\end{array}$} & \multirow[b]{2}{*}{ Kategori } \\
\hline & $\begin{array}{c}\text { Waktu } \\
\text { Pengambilan Data }\end{array}$ & $\begin{array}{c}\text { Temperatur } \\
\left({ }^{\circ} \mathrm{C}\right)\end{array}$ & $\begin{array}{c}\text { Kelembaban } \\
(\%)\end{array}$ & & \\
\hline \multirow{3}{*}{$\begin{array}{l}\text { Taman } \\
\text { Dipagga }\end{array}$} & Pagi & 28,0 & 98,9 & 27,90 & Tidak Nyaman \\
\hline & Siang & 33,2 & 61,2 & 30,60 & Tidak Nyaman \\
\hline & Sore & 30,9 & 70,7 & 29,12 & Tidak Nyaman \\
\hline \multirow{3}{*}{$\begin{array}{l}\text { Taman } \\
\text { Kalpataru }\end{array}$} & Pagi & 28,0 & 98,9 & 27,98 & Tidak Nyaman \\
\hline & Siang & 33,9 & 55,6 & 30,85 & Tidak Nyaman \\
\hline & Sore & 30,7 & 75,0 & 29,12 & Tidak Nyaman \\
\hline Embung & Pagi & 28,5 & 98,9 & 28,48 & Tidak Nyaman \\
\hline Taman Kota & Siang & 33,2 & 68,5 & 31,15 & Tidak Nyaman \\
\hline Way Halim & Sore & 29,4 & 76,3 & 28,04 & Tidak Nyaman \\
\hline
\end{tabular}

Taman Dipangga memiliki nilai THI sebesar 29,1 sedangkan Taman Kalpataru dan Embung Taman Kota Way Halim memiliki nilai THI yang sama yaitu 29. Temperatur udara yang sangat tinggi pada ketiga lokasi penelitian ini akibat area yang ditumbuhi pepohonan memiliki luas lebih sedikit dibandingkan dengan area terbuka di dalam taman maupun di area sekitar. Semakin banyak kawasan terbangun berupa beton dan perkerasan lain akan menyebabkan lebih banyak energi sinar matahari yang diubah menjadi energi panas sehingga temperatur semakin meningkat (Zahra, Sitawati dan Suryanto, 2014).

Berdasarkan analisis korelasi pada penelitian ini menyatakan bahwa kerapatan pohon berpengaruh nyata terhadap temperatur sebesar 0,992 . Hasil regresi menyatakan bahwa setiap kenaikan kerapatan 1 pohon/ha maka akan menurunkan temperatur udara sebesar $0,005^{\circ} \mathrm{C}$. Model ini memiliki selang kepercayaan sebesar 98,5\%. Hasil penelitian menunjukkan bahwa semakin rapatnya pohon yang ada di taman kota maka tem-peratur udara akan semakin rendah.

Dengan demikian, untuk memperbaiki kenyamanan termal terutama pada daerah-daerah yang memiliki nilai THI > 26 perlu penambahan RTH berupa tanaman peneduh dan tubuh air (Hayati, Sitorus dan Nurisjah, 2013). Jenis pohon yang mampu memperbaiki kenyamanan termal adalah jenis pohon peneduh yang memiliki percabangan di atas 2 meter dan bermassa daun padat seperti kiara payung (Filicium decipiens), tanjung (Mimusops elengi), dan angsana (Ptherocarphus indicus) (Departemen Pekerjaan Umum, 1996). Sebab suatu lokasi yang didominasi oleh tutupan lahan perkerasan tetapi ternaungi oleh kanopi pohon akan memiliki 
nilai THI yang lebih kecil dibandingkan dengan tutupan lahan berupa rumput dan tidak ternaungi oleh kanopi pohon (Hadi, Lila dan Gunadi, 2012). Pada ruang terbuka hijau terdapat faktor lain yang harus diperhatikan dalam kenyamanan yaitu kebisingan dengan tingkat baku ialah 50db (Keputusan Menteri Lingkungan Hidup, 1996).

\section{Penilaian Pengunjung}

Wawancara dilakukan pada 44 orang pengujung pada tiap taman, pengunjung diberikan pertanyaan sebanyak 30 butir dengan 16 kriteria mengenai fasilitas pada taman yang mempengaruhi kenyaman berkunjung/beraktivitas di taman tersebut yang berusia lebih dari sama dengan 17 tahun. Penilaian mengenai kenyamanan dan tersedianya fasilitas ini diperoleh dengan perhitungan skala likert dengan skor-skor yang telah ditentukan sebelumnya. Skor penilaian yang diperoleh dari ketiga taman tersebut ditunjukkan pada tabel 6 .

Tabel 6. Skor terhadap fasilitas kenyamanan taman.

\begin{tabular}{clccc}
\hline \multirow{2}{*}{ No. } & \multicolumn{1}{c}{ Kriteria } & \multicolumn{3}{c}{ Skor yang diperoleh } \\
\cline { 3 - 5 } & & $\begin{array}{c}\text { Taman } \\
\text { Kalpataru }\end{array}$ & $\begin{array}{c}\text { Taman } \\
\text { Dipangga }\end{array}$ & $\begin{array}{c}\text { Embung Taman } \\
\text { Kota Way Halim }\end{array}$ \\
\hline 1. & Akses & 3,44 & 3,24 & 3,29 \\
\hline 2. & Luasan Area & 3,62 & 2,24 & 2,84 \\
3. & Kesejukan & 2,69 & 2,91 & 2,56 \\
4. & Kerapihan & 1,87 & 2,13 & 1,44 \\
5. & Sarana Jalan & 2,07 & 2,40 & 1,80 \\
6. & Fasilitas Tempat duduk & 1,51 & 2,18 & 1,67 \\
7. & Fasilitas Toilet & 1,33 & 1,33 & 1,53 \\
8. & Fasilitas Beribadah & 1,40 & 1,36 & 2,09 \\
\hline 9. & Kebersihan & 1,91 & 2,62 & 1,58 \\
10. & Sarana Kantin/food court & 2,49 & 2,91 & 3,87 \\
11. & Sarana Olahraga & 2,09 & 1,40 & 1,96 \\
12. & Saran Tempat Bermain & 1,84 & 2,51 & 2,78 \\
& Anak & 2,69 & 3,02 & 2,80 \\
\hline 13. & Fasilitas Parkir & 2,64 & 3,36 & 2,64 \\
\hline 14. & Keamanan & 2,73 & 3,04 & \\
15. & Penerangan & & & \\
\hline
\end{tabular}

Keterangan:

Skor yang diperoleh; $1,00-1,99=$ Sangat Buruk

$$
\begin{aligned}
2,00-2,99 & =\text { Buruk } \\
3,00-3,99 & =\text { Baik } \\
4,00 & =\text { Sangat Baik }
\end{aligned}
$$

Pada Taman Dipangga pengunjung banyak berkunjung pada hari libur di waktu pagi dan sore hari sedangkan pada hari biasa pengunjung banyak berdatangan hanya pada sore hari. Tidak banyak fasilitas yang ditawarkan oleh Taman Dipangga sehingga aktivitas dominan pengunjung adalah hanya untuk duduk-duduk santai sesuai dengan persentase sebesar $61 \%$ dibandingkan dengan aktivitas lainnya.

Skor pada Tabel 6 menunjukkan bahwa pengunjung merasa nyaman terhadap taman karena memiliki keamanan yang baik dan akses menuju taman yang mudah dijangkau. Hal ini juga dinyatakan dalam (Arifin, Munandar, Nurhayati, Pramukanto dan Damayanti, 2007) bahwa taman kota adalah taman umum pada skala kota yang peruntukannya sebagai fasilitas 
untuk rekreasi, olahraga dan sosialisasi masyarakat di kota yang bersangkutan. Taman kota biasanya terletak di lokasi yang strategis dan mudah diakses dari berbagai penjuru kota.

Taman Dipangga yang berada tepat di depan Markas Polisi Daerah Povinsi Lampung memang mempengaruhi alasan dari keamanan yang baik dari penilaian pengunjung, sedangkan untuk akses menuju Taman Dipangga mudah dijangkau karena berada pada pusat kota dengan akses jalan maupun angkutan yang baik. Namun fasilitas toilet dan fasilitas beribadah mendapatkan skor terendah. Hal tersebut dapat terlihat pada Gambar 1 memang kondisi kedua fasilitas tersebut dalam keadaan rusak parah sehingga tidak dapat digunakan.

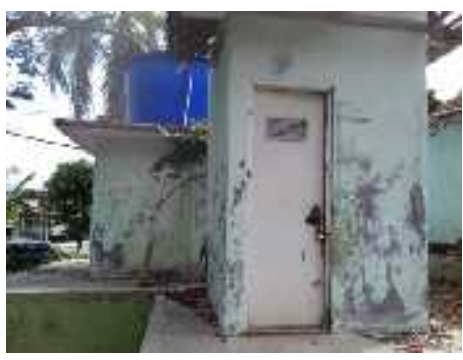

(a)

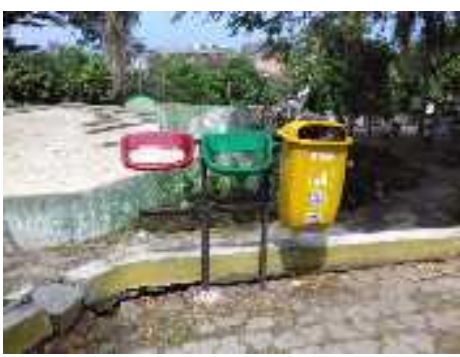

(b)

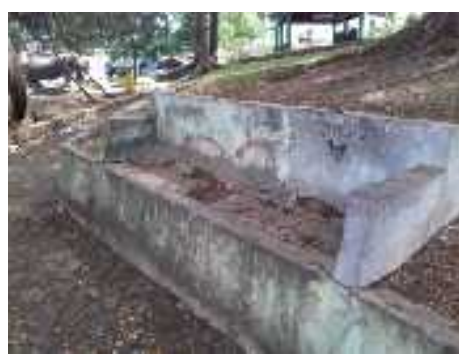

(c)

Gambar 1. (a) Fasilitas toilet yang rusak (b) Kotak sampah yang tidak dirawat (c) Fasilitas tempat duduk yang rusak di Taman Dipangga.

Hal serupa juga terlihat pada Taman Kalpataru yang memiliki beberapa fasilitas tidak terawat dan kebersihan taman dari sampah yang tidak terjaga dengan baik. Selain itu Taman Kalpataru juga memiliki fasilitas lain yang keberadaannya dinilai dalam kondisi sangat buruk. Fasilitas tersebut adalah fasilitas taman bermain anak dan toilet dapat dilihat pada Gambar 2.

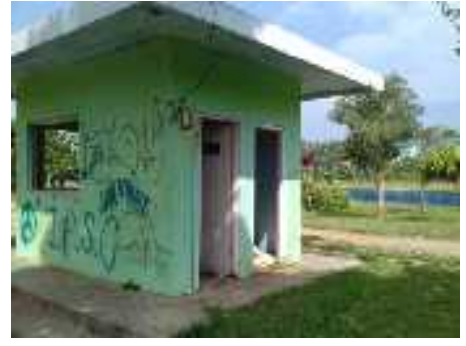

(a)

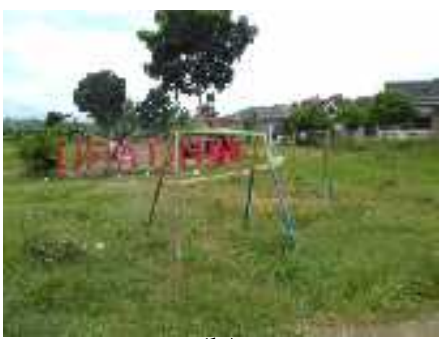

(b)

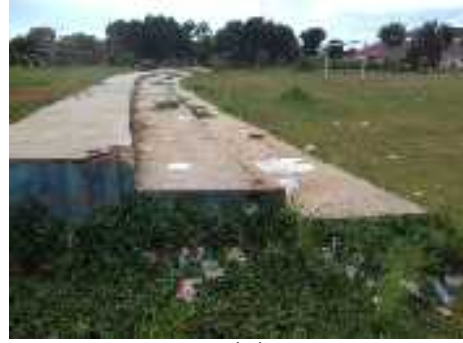

(c)

Gambar 2. (a) Fasillitas toilet yang rusak (b) Fasilitas tempat bermain anak yang tidak dirawat (c) Sampah yang berserakan di Taman Kalpataru.

Diketahui bahwa akses yang dekat menjadikan alasan utama untuk pengunjung pergi ke taman-taman tersebut. Umumnya tempat tinggal dari pengunjung tidak berada jauh dari lokasi taman. Sesuai dengan taman kota sebagai RTH publik yang berfungsi sebagai sarana warga bersosialisasi dan berekreasi warga kota yang bersangkutan (Arifin dkk, 2007), maka ketiga taman tersebut memang menjalankan fungsi pembangunannya dengan baik. Banyak pengunjung yang berprofesi sebagai ibu rumah tangga mengajak anak-anaknya untuk berkunjung ke taman dan bermain fasilitas yang telah disediakan. Fasilitas bermain anak yang mendapatkan skor buruk menjadikan fungsi sosial taman kurang maksimal.

Taman Kalpataru mendapatkan skor tinggi pada penilaian mengenai luas area. Area yang luas tersebut selain dijadikan sebagai fungsi taman, juga dimanfaatkan sebagai beberapa area lapangan. Terdapat lapangan sepak bola dan lapangan bola voli di dalam area taman. Hasil peresentase tertinggi kegiatan yang dilakukan saat berkunjung memang menunjukkan pada aktivitas olahraga yakni sebesar $45 \%$. 
Pada Embung Taman Kota Way Halim aktivitas yang dominan dilakukan tentunya adalah menyalurkan hobi memancing, dilihat dengan persentase sebesar 34\%. Hasil penelitian menunjukkan penilaian mengenai fasilitas penunjang yang ada di taman mendapatkan penlaian yang sangat buruk. Penilaian terburuk terdapat pada fasilitas kebersihan, kerapihan, fasilitas beribadah, fasiltas bermain anak dan lainnya padahal fasilitas-fasilitas yang telah disebutkan tadi merupakan fasilitas yang harus dimiliki setiap taman kota. Sedangkan penilaian baik diperoleh pada fasilitas olahraga karena didukung keberadaan lokasi Embung Taman Kota Way Halim yang berada di daerah Pusat Kegiatan Olah Raga (PKOR).

Skor yang diperoleh menunjukkan bahwa Taman Dipangga, Taman Kalpataru dan Embung Taman Kota Way Halim belum menyediakan fasilitas yang menunjang kenyamanan pengunjung. Renovasi sangat diperlukan untuk dilakukan pihak pengelola taman kota tersebut. Fasilitas yang sudah disediakan pada pembangunan awal seperti tempat duduk, toilet, taman bermain anak dan fasilitas lainnya yang mendapatkan skor rendah merupakan kegagalan dari pemeliharaan taman ideal.

\section{SIMPULAN DAN SARAN}

\section{Simpulan}

Berdasarkan tujuan dan hasil penelitian dapat diambil simpulan antara lain.

1. Taman Dipangga yang memiliki luas 0,68 hektar terdapat 43 pohon dari 10 jenis pohon dengan kerapatan sebesar 63,24 pohon/hektar. Taman Kalpataru yang memiliki luas 2,63 hektar terdapat 97 pohon dari 8 jenis pohon dengan kerapatan sebesar 36,88 pohon/hektar. Sedangkan pada Embung Taman Kota Way Halim yang memiliki luas 0,86 hektar terdapat 69 pohon dari 7 jenis pohon dengan kerapatan sebesar 80,23 pohon/hektar.

2. Taman Dipangga memiliki nilai THI sebesar $29^{\circ} \mathrm{C}$, Taman Kalpataru dan Embung Taman Kota Way Halim memiliki nilai TH sebesar $29,1^{\circ} \mathrm{C}$. Ketiga taman tersebut termasuk tidak nyaman.

3. Penilaian yang baik dari pengunjung mengenai fasilitas ketiga taman tersebut untuk dikunjungi hanya pada kemudahan akses dari tempat tinggal. Fasilitas kebersihan, fasilitas tempat beribadah dan fasilitas bermain anak menjadi kriteria fasilitas dengan penilain terburuk.

\section{Saran}

Diperlukan penelitian lebih lanjut dengan penambahan faktor lain yang berpengaruh pada kenyamanan, seperti kebisingan dan lainnya untuk memperkaya data dan informasi sehingga dapat menjadi dasar dalam menyusun perencanaan mengenai pembangunan dan pengembangan taman kota yang lebih baik.

\section{DAFTAR PUSTAKA}

Arifin, H.S.A. Munandar. N.H.S. Arifin, Q. Pramukanto, dan V.D. Damayanti. 2007. Sampoerna Hijau Kotaku: Buku Panduan Penataan Taman Umum, Penanaman Tanaman, Penanganan Sampah dan Pemberdayaan Masyarakat. Buku. Usaha Nasional. Jakarta. 188 p.

Arikunto, S. 2011. Prosedur Penelitian Suatu Pendekatan Praktik. Buku. Rineka Cipta. Jakarta. $256 \mathrm{p}$. 
Dahlan. 2011. Potensi Hutan kota Sebagai Alternatif Substitusi Fungsi Alat Pendingin Ruangan (Air Conditioner) (Studi Kasus di Kampus IPB Dramaga). Skripsi. Institut Pertanian Bogor. Bogor. 65 p.

Departemen Pekerjaan Umum. 1996. Tata Cara Perencanaan Teknik Lanskap Jalan. Buku. Direktorat Jendral Bina Marga. Jakarta. 58 p.

Hadi, R., Lila, K.A dan Gunadi, I.G.A. 2012. Evaluasi indeks kenyamanan taman kota (Lapangan Puputan Badung I Gusti Ngurah Made Agung Denpasar, Bali). Jurnal Agroekoteknologi Tropika. 2(1) : 44-45.

Hayati, J., Sitorus, S.R.P dan Nurisjah, S. 2013. Pengembangan ruang terbuka hijau dengan pendekatan kota hijau di Kota Kandangan. Jurnal Tata Loka. 15 (4) : 306 - 316.

Irwan, Z.D. 2005. Tantangan Lingkungan dan Lanskap Hutan Kota. Buku. Bumi Aksara. Jakarta. 300 p.

Irwan, S.N.R dan Kharuddin. 2010. Studi kenyamanan untuk aktivitas di Lanskap Hutan Kota UGM. Studi kasus : Klaster Agro UGM. Jurnal Ilmu Kehutanan. 4 (2) : 99-110.

Jogiyanto. 2005. Sistem Informasi Strategik untuk Keunggulan Kompetitif. Buku. Andi Publisher. Yogyakarta. 253 p.

Kartasapoetra A.G. 2004. Klimatologi: Pengaruh Iklim Terhadap Tanah dan Tanaman. Buku. PT Bumi Aksara. Jakarta. 113 p.

Kementerian Lingkungan Hidup Republik Indonesia. 1996. Keputusan Menteri Lingkungan Hidup No. 46 Tahun 1996 tentang Tingkat Baku Kebisingan. Jakarta

Mulyana, S. 2012. Kajian jenis pohon potensial untuk hutan kota di Bandung, Jawa Barat. Jurnal Analisis Kebijakan Kehutanan. 10 (1) : 58-71.

Mustika, S.W. 2001. Manfaat Ruang Terbuka Hijau dalam Menurunkan Temperatur Udara di Kawasan Perkotaan (DKI Jakarta). Skripsi. Institut Pertanian Bogor. Bogor. 87 p.

Nieuwolt, S dan Mc Gregor, G.R. 1998. Tropical Climatology. Buku. John Wiley \& Sons Ltd. England. $352 \mathrm{p}$.

Saputro, T.D., Fatimah, I.S dan Sulistyantara, B. 2010. Studi pengaruh area perkerasan terhadap perubahan temperatur udara. Jurnal Lanskap Indonesia. 2(2) :76-82.

Samadikun, B.P. 2007. Dampak perimbangan ekonomis terhadap Tata Ruang Jakarta dan Bopunjur. Jurnal Presipitasi. 2(1) : 34-38.

Sapariyanto., Yuwono, S.B dan Riniarti, M. 2016. Kajian iklim mikro di bawah tegakan Ruang Terbuka Hijau Universitas Lampung. Jurnal Sylva Lestari. 4 (3) : 114-123.

Zahra, A.F., Sitawati dan Suryanto, A. 2014. Evaluasi keindahan dan kenyamanan Ruang Terbuka Hijau (RTH) Alun-Alun Kota Batu. Jurnal Produksi Tanaman. 2 (7) : 524532. 